lis (on R. R. from Albany to coast) is good. Mary's Peak (4000 to $5000 \mathrm{ft}$.) in Coast Range, will repay a visit; take R. R. from Albany to Philomath, road 3 miles, trail 5 miles. Trail runs up through untouched forest; on summit is a large grassy pasture and a fine view of the Cascade Mts., including nine snowclad peaks.

Portland. Go up on the Heights and reconnoitre. Take trolley-car to Columbia slough for flower-loving insects. Do not miss trip by steamer up Columbia River to Hood River or Dalles east of Cascades, - an all-day ride. From Hood River one may go by stage to Cloud Cap Inn at timberline on Mt. Hood.

Western Washington is much like the Willamette Valley, but more thickly wooded. For forests try Ainslie or Napavine; for open mixed country Chehalis or Centralia. Tenino is very good, - stream, forest, clearings, prairie pastures, etc. Treeless gravel plains at Yelm Prairie. Fine old forests in vicinity of Wilkeson and Carbonado,
- by R. R. from Tacoma. Tacoma presents a good variety on the outskirts of the city,-salt-marshes, fields, forests, lakes and gravel plains 6 to ro miles southwest.

These are a few of the more desirable localities and chiefly those with which I became personally acquainted. There are, of course, many intermediate points that will repay examination if a relatively small area is covered or a particular section is to be investigated. The coastwise country may be reached by steamers from San Francisco or Portland and thence from port to port as opportunity offers, or in some cases by railroad or stage. If preferred, one may, at a slight increase of expense, secure a ticket over the Coast division of the So. Pacific R. R. between Los Angeles and San Francisco, thus reaching Santa Barbara, the Salinas Valley, and other portions of this region. A trip to the Yosemite Valley may be made from San Francisco (by steamer to Stockton, etc.) for less than from Berenda, the usual approach.

\title{
BUTTERFLY LIFE IN THE TROPICS OF INDIA.
}

[In a recent paper by Messrs. Davidson, Bell and Aitken on the butterflies of the North Canara district of the BombayPresidency, in which particular attention is paid to the early stages, we find the following passage, which presents in a few words a striking contrast to what is found in temperate regions and which may therefore interest our readers.]
Collectors in other parts of India often write of the number of broods in the year in terms which imply more regularity than we have observed in this moist and equable climate. $\mathrm{We}$ are not inclined to think that the majority of species here have any fixed number of broods in the year. One generation succeeds another as fast as conditions permit. It would be difficult to name 
any month in the year when many common species, such as Euploea core, may not be seen laying their eggs.

They are undoubtedly much more plentiful in some months than others, but this is because the largest number of larvae come to maturity at those times when succulent young leaves are most plentiful and enemies least active. Many species, however, pass through a certain portion of the year, which is unfavorable to them, in a state analogous to hibernation. For example the smaller Lycaenidae, such as Zizera, are not to be seen from June to August, when the heavy rain would beat down such feeble butterflies and drown their larvae. They appear in September and swarm for some months after. The same is true of Hypolimnas misippus, perhaps because it feeds on ground weeds, and the larva is liable to be drowned by heavy rain. On the other hand, H. bolina and the majority of the Nymphalinae and also the Papilioninae are much more abundant during the monsoon than at any other season. By the end of the year some of them have become very scarce, if they have not disappeared altogether, and it is evident that those which feed on deciduous plants cannot be in the larva state from December to March and later. The Pierinae, excepting Nepheronia, are less abundant during the rains than in the cold season, and Atella phalantha may be called a dryseason butterfly; its period of inactivity is the monsoon.

How each species tides over the par- ticular time which is unfavorable to it is an interesting question on which our knowledge is very limited. We have proved that Papilio nomius regularly remains in the pupa state from August till the following March or May; but this is a peculiar case. In $P$. clytia the pupa state is often prolonged for weeks or months without regard to season. But in the vast majority of species the pupae in our cages hatch on the due date as regularly as hen's eggs. Yet there are good reasons for thinking that it is in the pupa state that most butterflies pass through the time when nature is against them. It is also not improbable that eggs laid at an unfavorable time remain unhatched till next season. Lastly, some Hesperiidae hibernate in the larva state. The larva when full grown stops eating and shuts itself up in a cell as if it were about to become a pupa, but it does not actually undergo that change for some weeks or even months. We are not disposed to believe that in this climate the imago hibernates as it commonly does in Europe.

Apart from hibernation, the length of a larva's life varies a good deal according to the supply of food. When tender leaves are plentiful they grow fast. Butterflies of strong build and powerful flight, such as the Charaxes and the larger Hesperiidae, live much longer in the larva state than others. The duration of the pupa state, on the other hand, seems to depend on little else than size. Small Lycaenidae emerge in a week, the majority of medium-sized 
butterflies in ten days, and the Papilios in a fortnight. Troides (Ornithoptera) takes three weeks. (Journ. Bomb. nat. hist. soc., $\mathrm{X}, \mathrm{I}-3)$.

\section{THE ACRIDIAN SUBFAMILY MASTA- CINAE IN THE UNITED STATES.}

The American Mastacinae hitherto known are the genera Mastax and Masyntes, which have been reported only from South America and the West Indies.

In his collections on the Pacific coast last summer Mr. A. P. Morse obtained two specimens of an apterous and possibly immature Mastacid, one at Cahon Pass in southern California on July 19, the other on Mt. Wilson, Altadena, near Los Angeles, on July 27. They belong to a new generic type, most nearly allied to Masyntes Karsch but differing from it by having a more appressed head with less convex vertex, the fastigium prominent as in Masyntes but broadly convex instead of sulcate or laterally marginate, apically broadly rounded and not emarginate, the lateral carinae of the metazona much less pronounced, the posterior angle of the lateral lobes rectangulate and the spines of the hind tibiae of uniform length. The body is cinereous with a broad black median stripe on the vertex, and on the upper half of the lateral lobes of the pronotum, continued on the abdomen; the fore and middle legs are ruddy. The length of the body and of the hind femora is only $9 \mathrm{~mm}$. The genus may be called Morsea and the species californica. Samuel H. Scudder.

\section{EARLY STAGES OF TROPICAL BU'T'TERFLIES.}

IN another place in this number we have printed an extract from a paper by Messrs. Davidson, Bell and Aitken, on Bombay butterflies. This paper which appears in vol- umes $x$ and $x i$ of the Bombay journal is one of the most important contributions to our knowledge of the early stages of tropical butterflies that have appeared in recent years. It is accompanied by eight colored plates of caterpillars and chrysalids and is in continuation of a paper by two of the number in the same journal eight years ago, where six similar colored plates are given and notes of no less than 94 species which they had themselves reared. The present paper includes a list of the butterflies of the district, which they enumerate as 233 species and of these notes are given or referred to of the earlier stages of all but 36 . This is a remarkable showing.

\section{PROCEEDINGS OF THE CLUB.}

I4 January, I898. The I98th regular and 2 Ist annual meeting of the Club was held at I 56 Brattle St., Mr. A. P. Morse in the chair.

Reports from the several officers were received and the following persons elected for the ensuing year:-President, T. E. Bean ; secretary, Roland Hayward ; treasurer, Samuel Henshaw; librarian, Samuel $H$. Scudder; members at large of the executive. committee, J. W. Folsom and S. H.-Scudder.

The address of the retiring president, $\mathrm{Dr}$. H. G. Dyar, on the larvae of the Australian Eucleidae, was read by proxy. It is given elsewhere in this number.

Mr. R. Hayward showed a female specimen of Zarhipis integripennis sent him recently by Mr. L. E. Ricksecker of Santa Rosa, Cal. Mr. Ricksecker stated in a letter that he had obtained three females, from which he procured eggs. A few larvae were obtained, but they died soon after hatching. 

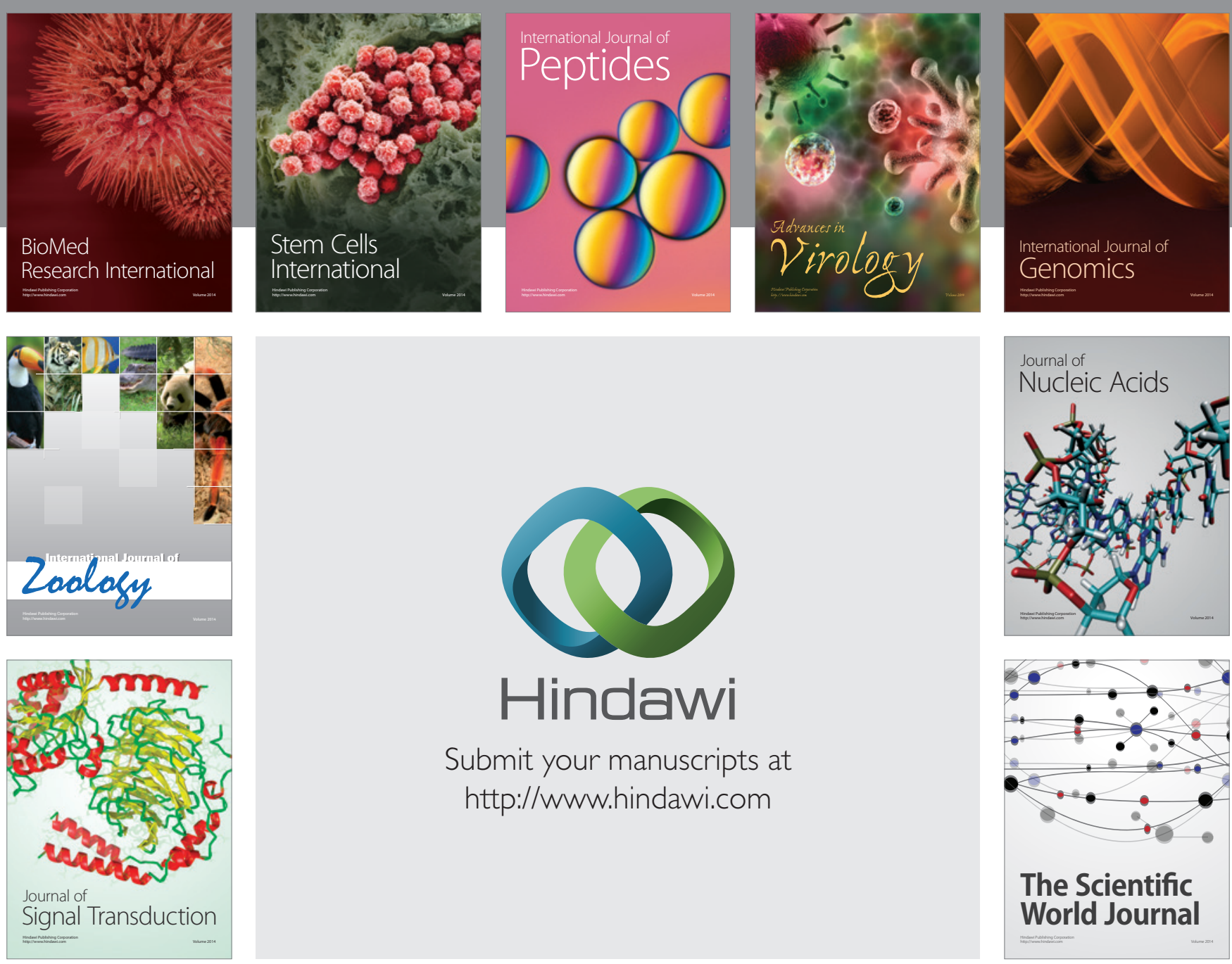

Submit your manuscripts at

http://www.hindawi.com
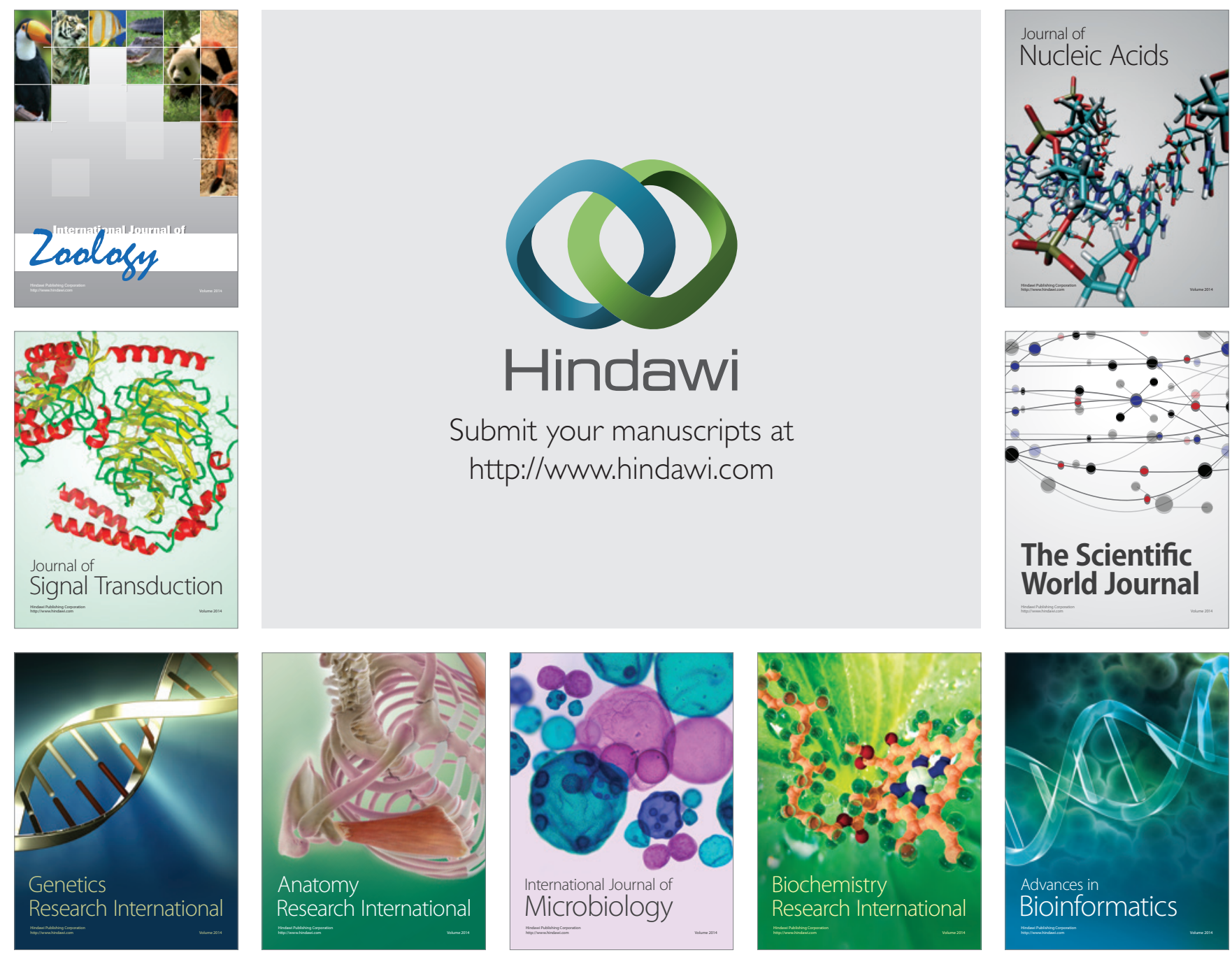

The Scientific World Journal
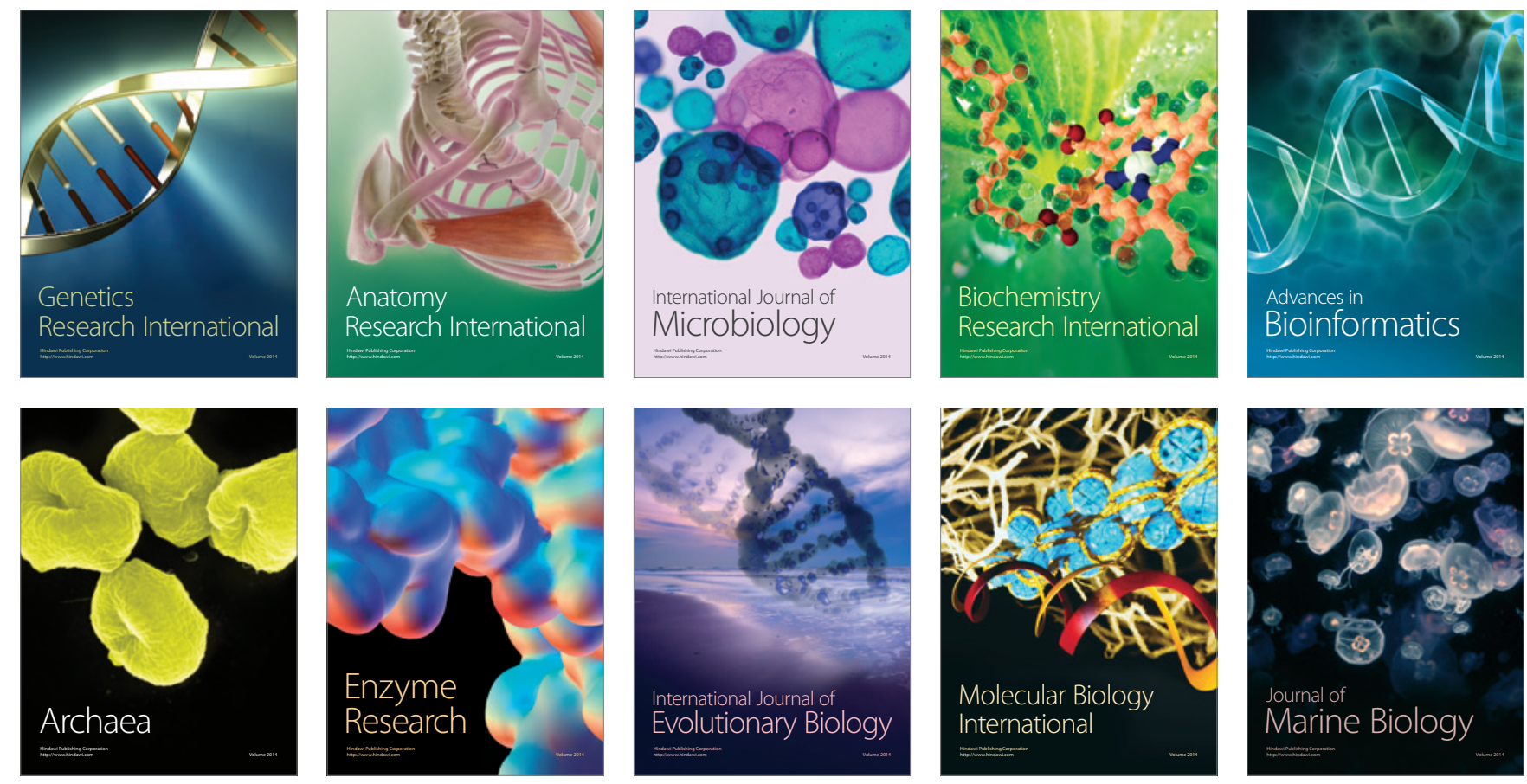